for $1866,1867,1868$, Prof. Agassiz ${ }^{1}$ had already called attention to the probable great antiquity of the oceanic basins.

Dr. Carpenter seems also to have overlooked the series of physical observations of the depths of the sea commenced by the United States Coast Survey ${ }^{2}$ in 1850 , and carried on without interruption to the present day.

The statement made by $\mathrm{Mr}$. Wild ${ }^{3}$ that the deepest sounding of the Tuscarora is not trustworthy, because "no sample of the bottom was brought up," is apparently endorsed by Dr. Car penter, who says: "The sounding wire of the United States ship Tuscarora twice broke without reaching bottom . . . . at depths considerably exceeding 4,000 fathoms." This should be modified by stating that the zirre broke while reeling in twice, once the bottom was not reached, and five casts were made over 4,000 fathoms, bringing up each time a specimen of the bottom. Capt. Geo. E. Bellinap, of the Titscarora, says, ${ }^{5}$ speaking of the casts beyond 4,000 fathoms in depth: "The wire parted at the last two and deepest casts. . . . the result of momentary carelessness on the part of the men at the recling-in zoheel."

The method of sounding with wire has now been in use long enough to show that even if the Tuscarora had not brought up a single specimen of the bottom during her whole trip, and if the wire had invariably broken while reeling in, we could not for that reason alone have rejected those soundings as inaccurate.

Those who have sounded with wire know that the instant the sinker has touched bottom is recorded on deck, and the precise depth is then known, whether the cylinder is brought up or not. There is no more reason for rejecting the deepest sounding of the Tuscarora of 4,655 fathoms than for rejecting the 480 other casts which are accepted because a bottom specimen came up.

Cambridge, Mass., April 5 Alexander Agassiz

\section{On the Alum Bay Flora}

IN the list of fossils appended to the paper upon the Alum Bay flora, brought before the Royal Society by Baron von Ettingsbausen and reported in NATURE, vol, xxi. p. 555, the new species have F.tt. and Gard. attached to them, implying that Ettingshausen and myself are their authors. It is only fair to Ettingshausen to state that $X$ had no share in making the determinations, and to myself, that I accept them simply as provisional. Associated as he is with me in the work npon the British eocene floras, he felt that he could hardly publish preliminary work connected with it in any other way. I completely disagree with him, however, as to the utility of publishing new specific names unaccompanied by drawings or descriptions of any kind, and think that a simple list of genera, with the number of new species in each, would have been unattended with any inconvenience. He appears to me to attach altogether undue weight to mere priority in nomenclature, and the existence of such provisional lists, far from aiding research, must prove a serious difficulty to our fellow workers. In the highly probable event of an author being unable to come from some distant country to examine the specimens themselves, is he, for instance, to forbear naming every undescribed species of such common Tertiary genera as Ficus, of which eight new and unpublished sfecies are in the list, of Celastrus, of which there are five, or of any other of the some fifty genera containing new specific names? He could not safely name even any indeterminable leaf or fruit, for fear it might be one of the long list of Phyllites or Carpolithes for which Ettingshausen has devised specific names.

I Bulletin of the Museum of Comp. Zoology, r869, vol. i., No. $x_{3}$. 2 Coast Survey Reports, I850 to present day; also Bibliograplyy of Liclogical Results (Bull. Mus. Comp. Zool., vol. v., No. 9, 1878).

3 "T"halassa," I8 77 , p. I5

4 "Deep-Sea Soundings in the North Pacific obtained by the United States ship Tusiarora" (Washington: Hydrographic Office, 1874 , No. 54 , p. $3^{\circ)}:-\rightarrow$

\footnotetext{
874. Fathoms.

June ix ... $4,643 \ldots$ Wire broke; botton not reached.

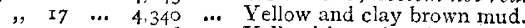

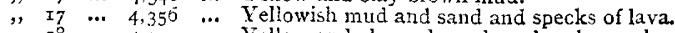

"I8 $\quad . . .44,04 \mathrm{I} \quad \ldots$ Yellow and clay-coloured mud and gravel.

" $\quad$ r8 $8 . . .4,234 \quad \ldots$ Rocky ; point of cylinder came up battered.

" 18 ... 4 , $120 \quad \ldots$... Vellow and clay-colouted mud mixed.

" I8 ... 4,4Ir $\ldots$... No specumen; wie broke (while reeling in).

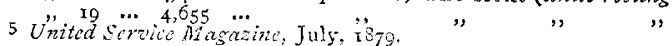

But were our supposititious author to go on with his work, in spite of this "sword of Damocles," would Baron Ettingshausen claim priority and deprive the man who had first figured and published descriptions of them, of the pleasure of christening them in accordance with his views and wishes? If not, cui bono?

To show the purely provisional light in which the list must be regarded, I may mention that, unfortunately just as the Baron left England, a large collection, that of the late M. Watelet from the Grès du Soissonnais, came into my possession, and seems, on a cursory examination, to contain a preponderance of species identical with those of Alum Bay. None of Watelet's published species appear in the list of the Alum Bay flora, which therefore must of necessity be considerably modified to include them. The same may be said of the flora of Gelinden, of which a large series has also reached me.

Again, even in the only section of plants yet worked out by us for the palæontographical memoir, the ferns, discrepancies occur. Two ferns occur in this Alum Bay list which are not included in our fern flora from that locality. These are inserted on the authority of Heer, who states that he has seen them from Alum Bay; but as on the occasion of that gentleman's visit or visits to England many years ago the floras from the different localities had not been systematically collected, and were generally mixed together in museums, in the same drawers and cases, and cannot always be identified by the matrix, I prefer to adhere to the opinion of that indefatigable collector, Henry Keeping, who lived within a short distance of Alum Bay, and to my own, Mr. Mitchell's, and all other workers' experience, that no fern but Marattia is found there. At all events, if they are to be included in the Alum Bay flora, they should be so with reserve, especially as Prof. Heer's ideas as to the position of the localities and their ages are so hazy that he puts the Alum Bay leaves in the "Bartonisem" (above, if anything), or about 1,00o feet too high, and thinks that Bournemouth is somewhere in the Isle of Wight.

An illustration of the inconvenience caused by publishing names without proper figures and descriptions occurs to me. Heer named a small fern fragment which he supposed to be from Alum Bay, Asplenium martinsi. This name has got into works by Saporta and Crié, who have each tried to fit ferns of their own into Heer's meagre description. Neither had seen the original, nor could they give any information, and it was only after several attempts to obtain it that Ettingshausen received a rough sketch from Heer showing conclusively that the "species" in question was a fragment of the abundant and well-known Anemia subcretacea of Sézanne. I do not even now know whether it was upon this fragment or some other that Heer wrote that he had "seen this form" (Anemia subcretacea) from Alum Bay.

J. STARIKIE GaRdNER

\section{Negritoes in Borneo}

HAVING had inquiries addressed to me as to the existence of a Negrito race in Borneo, I think it may be useful to recall attention to, and possibly save from oblivion, a statement on this subject which was published by Windsor Earl in the Fournal of the East Indian Archipelago. Mr. Earl says that a Capt. Brownrigg, who had been shipwrecked on the east coast of Borneo, informed him (F.E.I.A., No. 9) that he had lived several months at a town some distance up the Berau River, and that during his stay the town was once visited by a small party of men from the interior, "who must have been of the Papuan race" (sic). He described them as being short, strongly-built people, black in complexion, with hair so short and curly that the head appeared to be covered with little knobs like peas; and with many raised scarifications over the breast and shoulders. He described them as being on good terms with the people of the town, mostly Bugis, and as supplying them occasionally with jungle produce.

Of this account it may be remarked that Mr. Earl would not have retailed it unless he had had some confidence in the credibility of his informant--that, so far as it goes, it is curiously circumstantial-and that these people are said to have come exactly from that district in Borneo where we might expect $\grave{a}$ priori to find Negritoes if they existed at all.

Whilst on the subject of Borneo, may I suggest that ethnologists should malie a more sparing use of the term "Dyak" when treating of the Malay Archipelago? It should only be applied to tribes who themselves use it as the distinctive appellation of their people. As more than one tribe so uses it, there should always be prefixed some word still further limiting its applica- 